\title{
REVIEW
}

\section{Osteoporosis, genetics and hormones}

\section{R Rizzoli, J-P Bonjour and S L Ferrari}

Division of Bone Diseases, WHO Collaborating Center for Osteoporosis and Bone Diseases, Department of Internal Medicine, University Hospital, 1211 Geneva 14, Switzerland

(Requests for offprints should be addressed to R Rizzoli, Division of Bone Diseases, Department of Internal Medicine, University Hospital, CH-1211 Geneva 14, Switzerland;

Email: rizzoli@cmu.unige.ch)

\section{INTRODUCTION}

Osteoporosis is a systemic skeletal disease characterized by low bone mass and microarchitectural deterioration of bone tissue. At a given age, bone mass results from the amount of bone acquired during growth, i.e. the peak bone mass (Bonjour et al. 1991, Theintz et al. 1992) minus the age-related bone loss which particularly accelerates after menopause. The rate and magnitude of bone mass gain during the pubertal years and of bone loss in later life may markedly differ from one skeletal site to another, as well as from one individual to another. Bone mass gain is mainly related to increases in bone size, that is in bone external dimensions, with minimal changes in bone microarchitecture. In contrast, postmenopausal and age-related decreases in bone mass result from thinning of both cortices and trabeculae, from perforation and eventually disappearance of the latter, leading to significant alterations of the bone microarchitecture (Fig. 1).

\section{Peak bone mass acquisition}

Before puberty, there is no consistent genderrelated difference in bone mass at any skeletal site (Glastre et al. 1990, Bonjour et al. 1991, Geusens et al. 1991). Indeed, there is no evidence for a gender-related difference in bone mineral density (BMD; $\mathrm{g} / \mathrm{cm}^{2}$ ) at birth (Trotter \& Dixon 1974), and this similarity in bone mass between males and females is maintained until the onset of pubertal maturation (Gilsanz et al. 1988, 1991, 1998). During puberty, bone mineral mass of skeletal sites such as the lumbar spine more than doubles (Bonjour et al. 1991, Theintz et al. 1992). This increase occurs approximately 2 years earlier in females than in males (Fig. 2). Meanwhile, a gender-related difference in peak bone mass becomes detectable. This difference appears to result essentially from a longer period of bone mass gain in males than in females, resulting in a larger increase in bone size and cortical thickness in the former (Seeman 1997). Thus, the peak bone mineral content (BMC; g) at the lumbar spine and the proximal femur is higher in males than in females, whereas volumetric bone density $\left(\mathrm{g} / \mathrm{cm}^{3}\right)$ does not differ between genders at the end of pubertal maturation (Gilsanz et al. 1988, 1991, 1997, 1998). On the other hand, black people have greater volumetric bone density than white individuals (Gilsanz 1998, Gilsanz et al. 1998); trabecular number is similar, but the trabeculae appear to be thicker in black people (Han et al. 1996). Moreover, the cross-sectional area of the mid-femoral shaft is greater in black than in white individuals for an identical cortical thickness (Gilsanz et al. 1998).

There is an asynchrony between the gain in statural height and the gain in bone mass (Bonjour et al. 1991, Theintz et al. 1992, Fournier et al. 1997). The peak of statural growth velocity precedes the peak of maximal bone mass gain. In males, the greatest difference occurs in the 13- to 14-year age group and is more pronounced for the lumbar spine and femoral neck than for the mid-femoral shaft, whereas in females it occurs in the 11- to 12-year age group, corresponding in both genders to pubertal stages P2-P3 (Theintz et al. 1992). In healthy Caucasian females with apparently adequate intakes of energy, protein and calcium, bone mass accumulation can virtually be completed before the end of the second decade at both the lumbar spine and the femoral neck (Bonjour et al. 1991, Katzman 

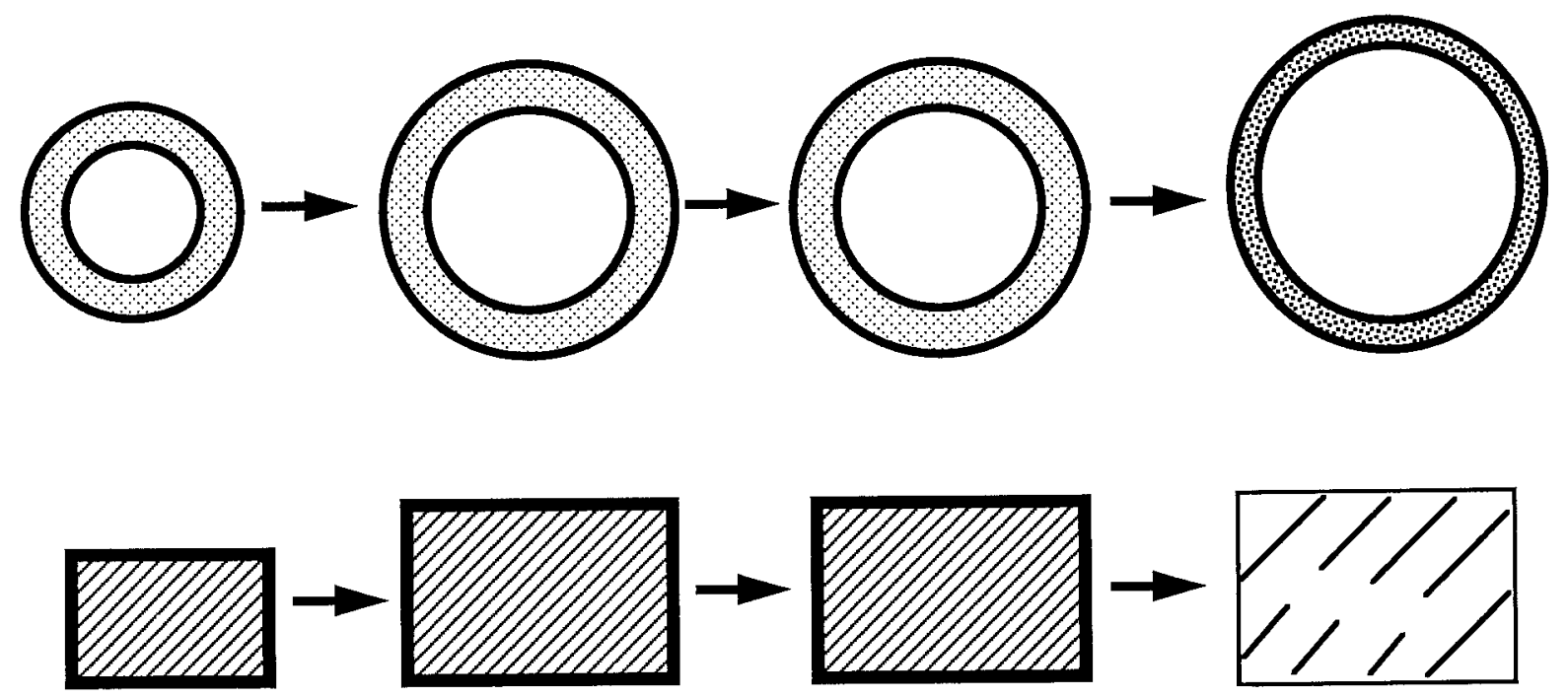

\section{Age: 10}

20

40

70

FIGURE 1. Schematic representation of cortical and cancellous bone changes throughout life. Stippling represents cortical porosity and hatching represents cancellous bone network.
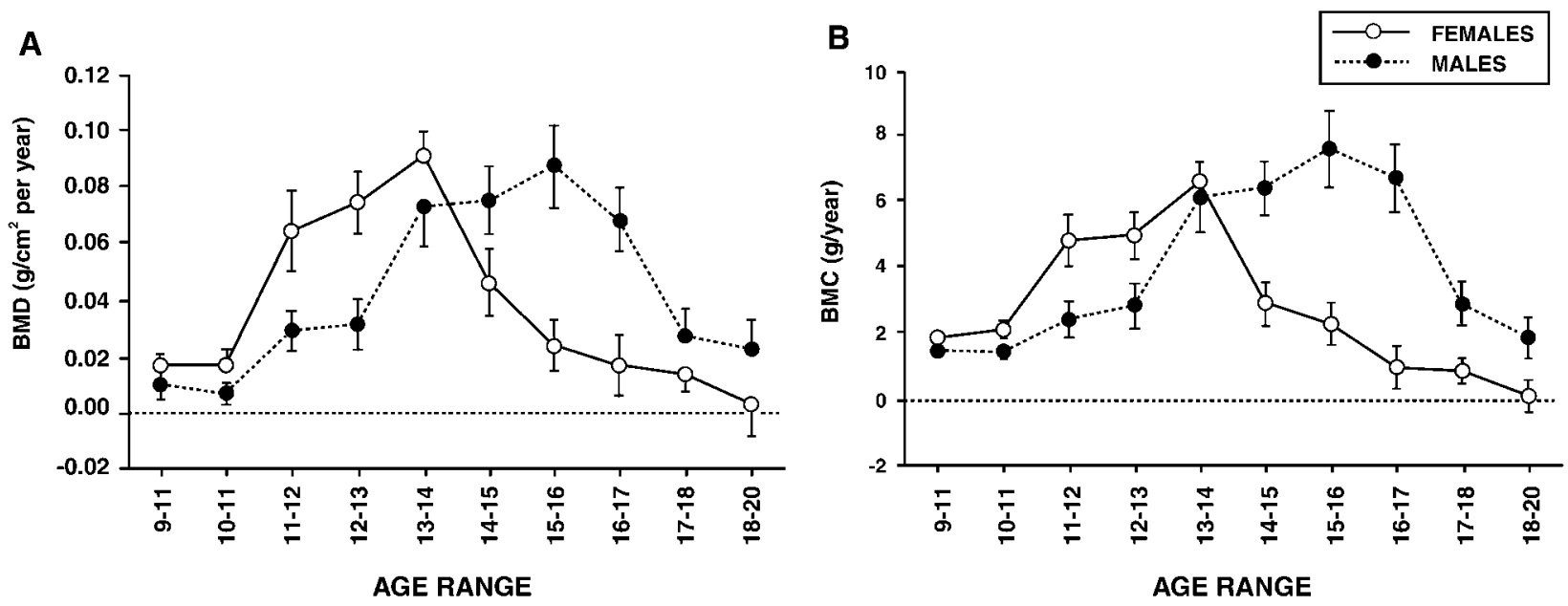

FIGURE 2. Mean \pm S.E.M. bone mass gain of the lumbar spine during adolescence (A: lumbar vertebrae L2-L4 BMD; B: lumbar vertebrae L2-L4 BMC). Reproduced with permission from Theintz et al. (1992).

et al. 1991, Theintz et al. 1992, Matkovic et al. 1994). In males, cortical bone mass may still increase by a few percent beyond the age of epiphyseal plate closure (Parsons et al. 1996).

\section{Bone loss}

Some bone loss seems to occur at distinct skeletal sites, such as the proximal femur, well before menopause (Riggs et al. 1986, Mazess et al. 1987,
Rodin et al. 1990, Luckey et al. 1996, Slemenda et al. 1996a). After peak bone mass is achieved, bone size varies little throughout life; a slight expansion of adult bone cortices can be found mainly in men (Garn et al. 1967, 1968, Mosekilde \& Mosekilde 1990, Seeman 1997). However, this periosteal expansion is less than the increase in bone marrow space resulting from the endosteal resorption which increases with age in both genders. Under these conditions, bone cortex becomes 
thinner (Fig. 1). This phenomenon, together with an increment in cortical porosity (Laval-Jeantet et al. 1983, Han et al. 1996) and a destruction of trabeculae, through thinning and perforation, account for the age-dependent bone loss. It is now clearly established that bone loss does not attenuate with age, but continues throughout life, at least in peripheral skeletal sites (Ensrud et al. 1995).

\section{ENDOCRINE REGULATION OF BONE MASS}

Many factors, more or less dependent on each other, are known to influence bone mass accumulation during growth. These determinants classically include genetic factors, which quantitatively appear the most prominent factors (Ferrari et al. 1998a, 1999), race, gender, nutrients (calcium, protein, phosphate), endocrine factors (sex steroids, calcitriol, insulin-like growth factor-I (IGF-I)), mechanical forces (physical activity, body weight), and exposure to risk factors (Bonjour \& Rizzoli 1996, Gilsanz 1998). Most of these factors are also involved in the maintenance of bone mass during adulthood as well as in bone loss later in life, although in variable proportions compared with their role in peak bone mass acquisition.

\section{The vitamin D system}

Vitamin $\mathrm{D}_{3}$ is for the most part synthesized from its 7 -dehydrocholesterol precursor in the dermis under ultra violet $\mathrm{B}$ radiations. It is sequentially hydroxylated by liver and kidneys in its hormonal metabolite, calcitriol, i.e. 1,25-dihydroxyvitamin D $\left(1,25(\mathrm{OH})_{2} \quad \mathrm{D}_{3}\right)$. The effects of $1,25(\mathrm{OH})_{2} \quad \mathrm{D}_{3}$ are mediated by its nuclear vitamin $\mathrm{D}$ receptor (VDR). Upon binding of $1,25(\mathrm{OH})_{2} \mathrm{D}_{3}$, VDR forms a heterodimeric complex with the retinoic acid receptor and additional transcription factors, and ultimately regulates the expression of a number of genes bearing vitamin $\mathrm{D}$ responsive elements in their promoter region (for review see Christakos et al. 1996, Haussler et al. 1997). The role of vitamin $\mathrm{D}$ metabolites is primarily to maintain serum calcium and phosphate levels by directly promoting intestinal absorption of these ions as well as by activating bone resorption (for review see Reichel et al. 1989).

Failure of the vitamin D endocrine system during growth causes rickets, which is a prominent bone-deforming and sometimes life-threatening disorder. Vitamin D is also important in the maintenance of skeleton integrity in adults. Elderly people tend to have poor dairy calcium and vitamin $\mathrm{D}$ intakes, decreased sunlight exposure and dermal production of vitamin $\mathrm{D}$, and diminished production of $1,25(\mathrm{OH})_{2} \quad \mathrm{D}_{3}$ with secondary hyperparathyroidism. In turn, vitamin $\mathrm{D}$ and calcium supplementation has been demonstrated to significantly increase BMD and decrease the incidence of osteoporotic fractures in the elderly (Chapuy et al. 1992, Chevalley et al. 1994, Dawson-Hughes et al. 1997).

\section{Estrogens}

Female sex hormones appear to be mandatory, not only for the acquisition of peak bone mass in both females and males (Smith et al. 1994, Carani et al. 1997, Vanderschueren et al. 1997), but also for the maintenance of bone mass in adults. They control bone remodeling during reproductive life in females (Rizzoli \& Bonjour 1997, Riggs et al. 1998) and later on in aging men (Slemenda et al. 1996b, 1997, Greendale et al. 1997). Pathologic conditions associated with premature estrogen deficiency, such as anorexia nervosa, secondary amenorrhea due to strenuous exercise, or the use of inhibitors of gonadotropin secretion, further support the concept of a causal link between estrogen deficiency and accelerated bone loss (Drinkwater et al. 1984, Seeman et al. 1992). By indirectly accelerating bone turnover and by uncoupling bone formation from resorption (Manolagas 1998), estrogen deficiency is the main cause of postmenopausal osteoporosis, and possibly plays an important role in male osteoporosis as well (Bilezikian et al. 1999). Thus, estrogen deficiency is directly implicated in the age-related increase in the incidence of fragility fractures (Riggs et al. 1998). In addition, estrogen deficiency also seems to be correlated with the progressive increase in serum parathyroid hormone (PTH) levels observed in aging individuals, which by itself contributes to accelerate bone turnover (Khosla et al. 1997).

\section{IGF-I}

IGF-I is an essential factor for longitudinal bone growth (Froesch et al. 1985), as it stimulates proliferation and differentiation of chondrocytes in the epiphyseal plate (Canalis et al. 1991). IGF-I also plays a role in trabecular and cortical bone formation. This factor can stimulate both proliferation and differentiation of osteoblasts; it increases type I collagen synthesis, alkaline phosphatase activity and osteocalcin production (Schmid \& Ernst 1992). Thus, IGF-I can exert anabolic effects on bone mass not only during growth, but also during adulthood (Rosen \& Donahue 1995, Ammann et al. 1996, Bagi et al. 1996, 1997). 
Furthermore, by its renal action on tubular reabsorption of phosphate and on the synthesis of calcitriol, through a direct action on renal cells (Caverzasio \& Bonjour 1989, Caverzasio et al. 1990), IGF-I can be considered as an important controller of the intestinal absorption and of the extracellular concentration of both calcium and phosphate, the main elements of bone mineral. On the other hand, IGF-I can selectively stimulate the transport of inorganic phosphate across the plasma membrane in some osteoblastic cell lines (Palmer et al. 1996, 1997). Osteogenic cells not only express specific IGF-I receptors, but they can also be endowed with IGF-I producing machinery (Canalis et al. 1991, Chevalley et al. 1998). Taking into account these experimental and clinical observations, IGF-I could play a prominent role in the pathophysiology of osteoporosis, of osteoporotic fracture and of its complications. In association with age, several reports have documented a decrement in IGF-I plasma levels (Hammerman 1987, Quesada et al. 1992, Goodman-Gruen \& BarrettConnor 1997, Langlois et al. 1998). Under these conditions, a restoration of this altered system in the elderly, for instance by protein replenishment (Schürch et al. 1998), is likely to favorably influence not only BMD, but also muscle mass and strength, since these two variables are important determinants of the risk of falling (Aniansson et al. 1984, Castaneda et al. 1995).

Thus, bone mass gain during childhood, bone loss after menopause and further loss in the elderly are determined by different sets of endogenous and exogenous factors (Ralston 1997, Seeman \& Hopper 1997), and the relative influence of specific genes on the risk of osteoporosis may vary greatly with age. We will now examine the genetic aspects of hormones and their receptors involved in the regulation of bone accumulation and loss.

\section{GENETIC DETERMINANTS OF OSTEOPOROSIS}

\section{Definition of the variable}

Although areal BMD is a continuous variable, an operational definition of osteoporosis considers the disease as a BMD below $-2 \cdot 5$ s.D. from the mean BMD of young adults for skeletal sites such as lumbar spine or proximal femur as evaluated by dual energy X-ray absorptiometry (DXA) (Kanis et al. 1996). This is the phenotypic trait (Rizzoli et al. 1995) that is most commonly used in studies evaluating heritability or polymorphic gene markers of osteoporosis. However, in order to understand the genetic basis for decreased bone strength, and ultimately osteoporotic fractures, one might eventually need to assess the inheritance of, and identify the specific genes associated with, a multitude of skeletal and extraskeletal traits, such as bone size, shape and microarchitecture (Turner et al. 2000), body weight (the single most influential variable correlated with BMD), muscle strength, biochemical variables of calcium and phosphate homeostasis, ovarian function, etc. Moreover, the clinical expression of osteoporosis is represented by the skeletal fracture. A fracture is a stochastic event which is determined by both bone-related factors (mass, size, architecture, microarchitecture, intrinsic properties of bone material) and boneindependent factors (falls, protecting responses, soft tissue padding, etc.) (Pinilla et al. 1996). The latter may have their own heritable and non-heritable components, which increases even further the complexity of the genetic determination of osteoporotic fractures (Kelly et al. 1990, Kannus et al. 1999, Zmuda et al. 1999).

\section{Heredity of bone mass}

It has been shown that daughters of osteoporotic women have a low BMD (Seeman et al. 1989). A study comparing peak bone mass at both the lumbar spine and femoral neck in young adult daughters from peri- and early postmenopausal women with decreased BMD and in daughters of women with normal BMD showed a decreased BMD among the former (Barthe et al. 1998). BMD is decreased among the relatives of 38 middle-aged men with severe idiopathic osteoporosis (Cohen-Solal et al. 1998). These studies confirm the importance of a familial history of osteoporosis in the screening of subjects at risk and suggest the expression of inherited determinants of the risk of osteoporosis from an early age on. A history of fracture is associated with a more than twofold increase in the risk of subsequent fracture (Klotzbuecher et al. 2000). In order to investigate the proportion of the BMD variance across the population explained by genetic factors, which is known as the heritability (Kelly et al. 1995), mainly two human models have been used. In the twin model, within-pairs correlations for BMD are compared between monozygotic (MZ) twins, who by essence share $100 \%$ of their genes, and dizygotic twins (DZ), who have $50 \%$ of their genes in common. Stronger correlation coefficients among adult MZ as compared with DZ twins are indicative of the genetic influence on peak bone mass, accounting for as much as $80 \%$ of lumbar spine and proximal femur 
BMD variance (Pocock et al. 1987). The influence of environmental and genetic factors on bone mass, but also on lean and fat mass has recently been reassessed in 102 female twin pairs (mean age \pm S.D. $52 \cdot 8 \pm 13$ years) from the Sydney Twin Study of Osteoporosis (Nguyen et al. 1998). Results indicate that $80 \%$ and $65 \%$ of variance of lean mass and fat mass, respectively, were attributable to genetic factors. However, genetic factors affecting lean and fat mass had only little influence on BMD at the lumbar spine or femoral neck. These results differ from the previous evidence of indirect genetic effects on bone mass occurring through the determination of lean body mass (Seeman et al. 1996). Hence it remains presently unclear whether the relation between lean mass and bone mass is most significantly determined by environmental or genetic influences.

Parent-offspring comparisons have also shown significant relationships for BMD, albeit heritability estimates have been somewhat lower (in the range of 60\%) than in the twin model (Tylavsky et al. 1989). Actually, the magnitude of direct genetic effects on peak bone mass as evaluated in both human models may be overestimated by similarities in environmental covariates (Slemenda et al. 1991, Krall \& Dawson-Hughes 1993). We investigated correlations for BMC, areal and volumetric BMD and bone area in the lumbar spine and femur (neck, trochanter and diaphysis) in 138 premenopausal women (mean age \pm s.D., $40 \cdot 0 \pm 4 \cdot 0$ years) and their prepubertal daughters $(8 \cdot 1 \pm 0 \cdot 7$ years) (Ferrari et al. 1998b). Regressions were adjusted for height, weight and calcium intake, to minimize the impact of indirect genetic effects as well as of dietary influences on bone mineral mass resemblance among relatives. The results indicate that despite great disparities in the maturity of the various constituents of bone mass before puberty with respect to peak adult values, heredity by maternal descent is detectable at all skeletal sites and affected virtually all bone mass constituents, including bone size and volumetric mineral density. Moreover, when the daughters' bone values were re-evaluated 2 years later, while puberty had begun and bone mineral mass had considerably increased, measurements were highly correlated with prepubertal values (all $r>0 \cdot 80$ ) and mother-daughter correlations had remained unchanged. By the age of 16-18 years in females and 18-20 years in males, bone mass gain virtually ceases, but a marked scattering of BMD values for both genders is then apparent across the population (Bonjour et al. 1991, Theintz et al. 1992). Thus, a major proportion of this variance is due to genetic factors which are already expressed before puberty with subsequent tracking of bone mass constituent through the phase of rapid pubertal growth until peak bone mass is achieved.

A twin study using quantitative ultrasound to evaluate bone properties in the phalanges and calcaneum has shown heritability values ranging from $55 \%$ to $82 \%$, which is similar to BMD values estimated by DXA at the lumbar spine and femoral neck level (Danielson et al. 1999). However, cross-trait correlations suggested that specific genes unrelated to BMD explained at least half of the heritability of ultrasound measurements. Hence the risk for osteoporosis and osteoporotic fracture is determined by various sets of genes whose effects may not all be appreciated by one single measurement, such as BMD. Interestingly, it appears that male to male, and male to female inheritance of bone mass may differ substantially (Krall \& Dawson-Hughes 1993). It might be hazardous therefore to extrapolate genetic influences on bone mineral mass as identified in women to the male population, in which this question has virtually not yet been investigated.

In contrast to the clear heritability of peak bone mass, the proportion of the variance in bone turnover as well as in postmenopausal and age-related bone loss which depends on genetic factors remains unclear. Twin studies have suggested a higher correlation for bone loss among MZ compared with $\mathrm{DZ}$ twins (Kelly et al. 1995), but the heritability of bone turnover, as assessed in this model by various markers of bone formation and resorption, appears to be small (Garnero et al. 1996a). Interestingly, however, the age at which cessation of the ovarian function occurs, which is a major determinant of the osteoporosis risk (see above), seems to display a strong heritability (63\%) (Snieder et al. 1998).

\section{Candidate genes versus genome screens}

As pointed out before, osteoporosis is very likely to be a polygenic disease, involving a large variety of gene products implicated in both bone modeling (growth) and remodeling (loss). Genetic linkage between BMD and candidate genes has been searched in twin cohorts of unaffected individuals, in large numbers of both affected (osteoporotic) and unaffected unrelated individuals (case controls and association population studies) and, rarely, in osteoporotic probands and relatives. The latter case is best illustrated by the study of Duncan et al. (1999) who used a linkage approach to test a number of candidate genes known to be implicated in the control of BMD and/or bone metabolism in 115 probands with osteoporosis and 499 relatives. The candidate genes studied coded for structural 
TABLE 1. Frequency of common allelic polymorphisms in candidate hormone or homone receptor gene loci associated with bone mass

\section{Genotype frequency}

\begin{tabular}{|c|c|c|c|}
\hline & Markers & Caucasian & Asian \\
\hline \multicolumn{4}{|l|}{ Gene loci } \\
\hline \multirow[t]{3}{*}{ Vitamin D receptor $3^{\prime}$ end } & BsmI & BB $18 \%$, Bb 46\%, bb 36\% & BB $1-2 \%$, Bb $21 \%$, bb $77 \%$ \\
\hline & TaqI & TT $36 \%$, Tt $48 \%$, tt $16 \%$ & TT $78 \%$, Tt $21 \%$, tt $1 \%$ \\
\hline & ApaI & AA $24 \%$, Aa $46 \%$, aa $28 \%$ & AA $9 \%$, Aa $48 \%$, aа $43 \%$ \\
\hline Vitamin D receptor start codon & FokI & FF $36 \%$, Ff $49 \%$, ff $15 \%$ & FF $33 \%$, Ff $53 \%$, ff $14 \%$ \\
\hline \multirow{2}{*}{ Estrogen receptor } & PvuII & PP $18 \%$, Pp $53 \%$, pp $29 \%$ & PP $18 \%$, Pp $52 \%$, pp $30 \%$ \\
\hline & $X b a \mathrm{I}$ & $\mathrm{XX} 10 \%, \mathrm{Xx} 48 \%, \mathrm{xx} 42 \%$ & $\mathrm{XX} 5 \%, \mathrm{Xx} 31 \%, \mathrm{xx} 64 \%$ \\
\hline Parathyroid hormone & $B s t \mathrm{BI}$ & $\mathrm{ND}$ & BB $82 \%$, Bb $17 \%$, bb $1 \%$ \\
\hline Glucocorticoid receptor exon 2 & $\mathrm{~A}^{1220}-\mathrm{G}^{*}$ & Heterozygous 6\% & ND \\
\hline \multirow[t]{2}{*}{ Calcitonin receptor } & $\mathrm{C}^{447}-\mathrm{T}^{*}$ & RR $49 \%, \operatorname{Rr} 44 \%, \operatorname{rr} 7 \%$ & ND \\
\hline & TaqI & TT $11 \%$, Tt $50 \%$, tt $39 \%$ & ND \\
\hline Insulin-like growth factor-I & $\mathrm{CA}$ repeat & ND & (6 genotypes) \\
\hline
\end{tabular}

components, such as type I collagen A1 and A2, type II collagen A1, fibrillin type 1, or osteopontin, for growth factors or cytokines, such as colony-stimulating factor 1, epidermal growth factor, interleukin (IL)-1 $\alpha$, IL-4, IL-6, IL-11, transforming growth factor- $\beta 1$ (TGF- $\beta 1$ ), tumor necrosis factor $\alpha$ and $-\beta$, or components of endocrine systems, such as androgen receptor, VDR, calcium-sensing receptor, estrogen receptor (ER)-1, IGF-I, PTH, PTH-related protein (PTHrP), and PTH receptor type 1 . The strongest linkage with BMD was detected with the PTH receptor type 1 gene, with a maximal LOD (logarithm of the odds) score of of $2 \cdot 7-3 \cdot 5$. The ER type 1 gene and the IL-6 gene were among the few other loci to be significantly associated with BMD, but with lower LOD scores.

Alternatively, genome-wide scanning in large kindreds with a clearly defined skeletal phenotype, such as autosomal recessive juvenile onset osteoporosis (Gong et al. 1996) or high bone mass (Johnson et al. 1997), as well as in the population at large (Koller et al. 1998) have been performed. These genome screens have localized important quantitative trait loci linked to bone mass, such as chromosome 11q12-13 (see references above), which now require further studies to eventually identify the specific genes involved.

As far as endocrine systems are concerned, polymorphic candidate genes coding for hormones and/or their receptors known to control calcium/ phosphate and bone metabolism have been particularly scrutinized for their association with BMD and/or osteoporosis in population studies. These studies are reviewed in some detail below.

\section{VDR gene polymorphisms}

Among the multiple candidate genes harboring polymorphic loci so far investigated in relation to BMD and/or BMD changes (Table 1), the VDR-3' end alleles (BsmI, ApaI and $T a q \mathrm{I})$ were the first described (Morrison et al. 1994) and the most controversial (Hustmyer et al. 1994, Garnero et al. 1995, 1996b, Cooper \& Umbach 1996, Jørgensen et al. 1996, Matsuyama et al. 1995, Tokita et al. 1996, Uitterlinden et al. 1996, Zmuda et al. 1997, Kikuchi et al. 1999). A meta-analysis combining 16 separate studies examined the relationship between VDR genotypes and BMD (Cooper \& Umbach 1996). Subjects with the BB genotype had a $2 \cdot 4 \%$, $2 \cdot 5 \%$ and $1 \cdot 7 \%$ non-significantly lower BMD as compared with bb at the level of the femoral neck, lumbar spine, and distal radius respectively. Regarding vertebral fractures (368 cases and 1548 controls, collected in five studies), the relative risk in $\mathrm{BB}$ versus bb subjects varied between 0.7 and 2.5 among studies. All confidence intervals included 1 and none reached a level of statistical significance. For hip fracture, there were 235 cases and 800 controls in two cohorts. Although the relative risk of femoral neck fracture among BB in the Nurses' Health Study was $2 \cdot 4$, reaching statistical significance when older age and lower calcium intake were taken into consideration (Feskanich et al. 1998), these results were not confirmed in the Study of 
Osteoporotic Fractures, which found a relative risk of $0 \cdot 8$ for BB (Ensrud et al. 1999).

Based on the assumption that quantitative ultrasound measurements (QUS) of the calcaneum (broadband ultrasound measurement and speed of sound) might evaluate some properties of bone which differ from BMD at other sites as assessed by DXA, two studies have recently examined the relationship between VDR alleles and QUS in, respectively, 393 women aged 45-53 years (Gregg et al. 1999) and 425 postmenopausal women (Giguère et al. 2000). No significant association was found between VDR-3' polymorphisms and QUS measurements in either study.

The more recently described association between VDR-5' start codon polymorphism (FokI) and BMD, at first observed in small cohorts of postmenopausal Mexican-American women (Gross et al. 1996), white premenopausal American women (Harris et al. 1997) as well as Japanese women (Arai et al. 1997), has not been confirmed in two larger European studies in healthy premenopausal women or prepubertal girls (Eccleshall et al. 1998, Ferrari et al. 1998d).

Several independent investigators have shown the importance of age, gene-environment interactions and gene-gene interactions to explain the inconsistent relation between bone mineral mass and VDR-3' and $-5^{\prime}$ genotypes. Thus, significant BMD differences between VDR-3' BsmI genotypes were detected in children (Sainz et al. 1997, Ferrari et al. 1998c), but were absent in premenopausal women from the same genetic background (Ferrari et al. 1998c). Moreover, the latter study found that BMD gain in prepubertal girls was increased at several skeletal sites in $\mathrm{Bb}$ and $\mathrm{BB}$ subjects in response to calcium supplements $(800 \mathrm{mg} /$ day $)$, whereas it remained apparently unaffected in bb girls, who had a trend for spontaneously higher BMD accumulation on their usual calcium diet (Ferrari et al. 1998c) (Fig. 3). Accordingly, a model taking into account the early influence of VDR-3' polymorphisms, calcium intake and puberty on BMD gain has been proposed to explain the relation between these genotypes and peak bone mass (Ferrari et al. 1998a). Interestingly also, several investigators have noted a significantly lower height among women and men with the VDR-3' BB compared with $\mathrm{Bb}$ or bb genotypes (Barger-Lux et al. 1995, Ferrari et al. 1998c, Tao et al. 1998, Lorentzon et al. 2000). Considering the relationship between body size and bone size, as well as the influence of calcium intake on both body height and bone area during growth (Bonjour et al. 1997), it is tempting to speculate that VDR-3' alleles together with environmental calcium might have an indirect and complex influence on

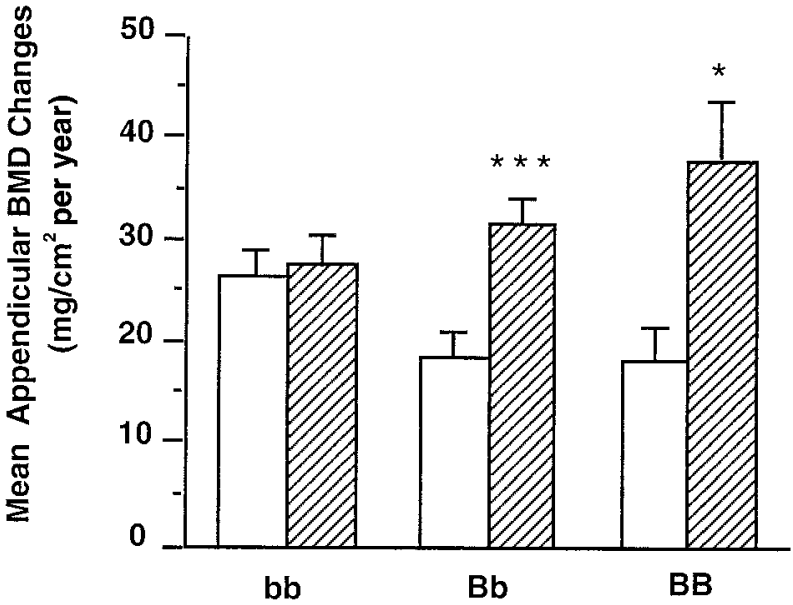

FIGURE 3. Mean BMD changes of five appendicular skeleton sites (radial metaphysis and diaphysis, femoral neck, trochanter and shaft) in prepubertal girls receiving a $850 \mathrm{mg}$ calcium supplement (hatched bars), or a placebo (open bars), during 1 year, according to VDR-3' end genotypes. The results are taken with permission from Bonjour et al. (1997) and Ferrari et al. (1998a). $* P<0 \cdot 05$, *** $P<0 \cdot 001$.

peak bone mass through the regulation of skeletal growth. A number of investigators have shown a significant interaction between VDR-3' genotypes and calcium intake on BMD in young adult and postmenopausal women (Salamone et al. 1996, Kiel et al. 1997, Rubin et al. 1999) as well as on BMD changes and/or intestinal calcium absorption in late postmenopausal women (Dawson-Hughes et al. 1995, Ferrari et al. 1995, Krall et al. 1995). The latter observation is particularly important, considering that postmenopausal women with low fractional calcium absorption and low calcium intake are at a significantly increased risk of hip fracture (Ensrud et al. 2000). Moreover, VDR-3' alleles have been associated with BMD changes in response to vitamin D supplementation in a small group of elderly women (Graafmans et al. 1997).

A short-term dietary intervention trial in young healthy males segregated as alternate homozygous $\mathrm{BB}$ and $\mathrm{bb}$ according to VDR-3' Bsm I alleles further suggests that BB subjects may have a subtle resistance to calcitriol leading to significantly higher levels of circulating PTH, decreased tubular reabsorption of inorganic phosphate $(\mathrm{Pi})$ and lower serum Pi levels when their calcium and phosphorus intakes are maintained at the lowest levels for several days (Ferrari et al. 1999). In addition, age and dietary calcium intake might also influence the association between VDR-5' start codon polymorphisms and peak bone mass (Ferrari et al. 1998d). Moreover, similarly to VDR-3' alleles (see above), 
VDR-5' alleles have also been associated with intestinal calcium absorption in children, as evaluated by a radioisotopic method (Ames et al. 1999). Altogether, these observations provide a possible physiological mechanism to the relation between VDR gene polymorphisms and bone mass and emphasize the methodological limitations of early studies focusing on the association between VDR genotypes and BMD regardless of the influence of age and environmental factors. Moreover, other potential gene-environmental interactions, such as those involving physical exercise (Gregg et al. 1996) as well as gene-gene interactions might further modulate the relationship between VDR gene polymorphisms and bone mass.

Thus, BMD differences (equivalent to 1 s.D.) have been found in prepubertal girls, premenopausal women and young adult males segregated according to both VDR-3' BsmI and VDR-5' $F_{o k} \mathrm{I}$ genotypes whereas, taken independently, these polymorphisms were either not associated or only weakly associated with BMD (Ferrari et al. 1999). Gene-by-gene interactions have also been found between VDR and ER gene polymorphisms and are examined below.

In summary, VDR-3' and $-5^{\prime}$ alleles are possibly weak determinants of BMD, their effects being easily confounded by the influence of many other genes and environmental factors. Hence, VDR gene polymorphisms alone are not clinically useful genetic markers of the osteoporosis risk in the elderly. Nevertheless, when examining the effects of calcium on peak bone mass (and particularly bone size) acquisition (bone modeling), or on bone loss (bone remodeling), VDR alleles could be one significant factor to explain some of the variability observed in the population.

\section{ER gene polymorphisms}

Genotypes identified by PvuII and XbaI restriction fragment length polymorphisms in the first intron of the ER $\alpha$ gene (Table 1) were originally found to be significantly associated with BMD in postmenopausal Japanese women, but not with markers of bone turnover (Kobayashi et al. 1996). In contrast, a similar study from Korea reported no significant BMD differences among ER genotypes in postmenopausal women receiving hormone replacement therapy (HRT) (Han et al. 1997). Whereas the former study suggested that ER gene polymorphisms could be related to the acquisition of peak bone mass, the latter rather suggested an influence, if any, on the rate of bone loss. More recently, another study from Japan including 173 premenopausal to late postmenopausal women indicated a predominant association between ER genotypes and adult bone mass, which disappeared with advancing age (Mizunuma et al. 1997). Several investigators have examined ER gene polymorphisms and bone mass in Caucasian populations as well. In one study, a significant association was found between either the PvuII or the $X b a \mathrm{I}$ genotypes and lumbar spine BMD in 253 pre- and perimenopausal women, those with the PvuII pp genotype having a $6 \cdot 4 \%$ lower BMD at this site compared with PP (Willing et al. 1998). However, there were no differences in BMD changes, nor in several biochemical markers of calcium and bone metabolism, including PTH and osteocalcin, over a 3 -year period in this cohort. One limitation of this study concerning the potential association of ER polymorphisms with postmenopausal bone loss was the very low overall bone loss in this cohort over 3 years $(\leq 1 \%)$. In contrast, a very recent study which prospectively investigated the 5-year bone loss in early postmenopausal women receiving either HRT or placebo in addition to calcium and vitamin $\mathrm{D}$ found no significant differences in BMD among ER polymorphisms at baseline, but significant differences in lumbar spine BMD changes between ER genotypes PP $(-6.4 \%)$ and pp $(-2.9 \%)$ in the absence of HRT (Salmen et al. 2000). In women receiving HRT, these differences were no more apparent.

A significant gene-by-gene interaction between VDR and ER gene polymorphisms has been suggested by several authors. In the study by Willing et al. (1998), BMD at all skeletal sites was lower in subjects with the VDR BsmI genotype BB, as compared with $\mathrm{Bb}$ and $\mathrm{bb}$, in the subgroup of women carrying the ER PvuII genotype PP. Of note however, there were only five VDR/ER BB/PP in this cohort. An interaction between VDR-3' and ER polymorphic loci has also been suggested in relation to BMD in a cohort of 426 normal and osteoporotic early postmenopausal women (Gennari et al. 1998). Subjects carrying the VDR/ER BB/PP genotype had a significantly lower BMD at the lumbar spine compared with alternate homozygotes $\mathrm{bb} / \mathrm{pp}$. VDR/ER polymorphisms have also been related to the rate of postmenopausal bone loss in a small cohort of women $(n=108)$ with or without HRT (Deng et al. 1998). These results, however, remain controversial, as a recent study in 313 late postmenopausal women with a low average calcium intake (approximately $600 \mathrm{mg} /$ day), including 142 women with a history of osteoporotic fractures, found no significant relationship between ER polymorphisms alone or in combination with VDR polymorphisms on BMD or a panel of biochemical markers of calcium and bone metabolism (Vandevyver et al. 1999). 
Altogether, these data suggest that $\mathrm{ER} \alpha$ gene alleles PvuII (alternatively $X b a \mathrm{I}$ ) may be another possible determinant of bone mass, particularly through their interaction with VDR-3' alleles and estrogen replacement therapy in postmenopausal women. The molecular mechanisms of these potential interactions as well as their value to identify responders versus non-responders to HRT remain completely unknown.

\section{IGF-I gene polymorphisms}

The IGF-I gene is a recent new candidate in relation to bone mass (Miyao et al. 1998, Rosen et al. 1998). Numerous alleles are identified by the number of CA repeats in the vicinity of promoting regions in the IGF-I gene, $1 \mathrm{~kb}$ upstream from the transcription start (Weber \& May 1989). Men with idiopathic osteoporosis had low serum IGF-I, and this was associated with homozygosity for a specific allele of the IGF-I microsatellite characterized by 192 CA repeats (Rosen et al. 1998). This genotype has then been shown to be associated with lower peak serum IGF-I levels and lower femoral cross-sectional area in 85 pubertal boys and girls (Gilsanz et al. 1999). However, these findings were not confirmed in healthy postmenopausal Japanese women (Miyao et al. 1998), in 363 premenopausal women (Takacs et al. 1999), in 256 healthy Caucasian adolescents of both genders below the age of 20 (Berg et al. 2000), nor in 100 adult young males at the peak bone mass (Rizzoli et al. 2000). Hence, despite the clear role of the growth hormone-IGF-I axis on the development and maintenance of peak bone mass, the adequacy of IGF-I CA repeat polymorphisms as susceptibility markers for the risk of low bone mass/osteoporosis requires further evidence.

\section{Other hormones/receptor gene polymorphisms}

Several other polymorphic genes coding for hormones and/or the receptor have recently been investigated in relation to bone mass (Table 1) (Huizenga et al. 1998, Masi et al. 1998, Miyao et al. 1998, Rosen et al. 1998, Taboulet et al. 1998, Willing et al. 1998, Hosoi et al. 1999, Kanzawa et al. 1999, Sowers et al. 1999, Heishi et al. 2000) and some clearly deserve further attention. An allelic variant causing an amino acid change in the C-terminal domain of the calcitonin receptor gene has been identified (Masi et al. 1998, Taboulet et al. 1998, Tsukamoto \& Emi 1998). In two of these studies, heterozygous $\mathrm{Rr}$ postmenopausal women had an apparently higher BMD as compared with either homozygote RR or rr. The lack of a clear allele dosage effect casts some doubts on the pertinence of these observations. Polymorphisms in the glucocorticoid receptor gene resulting in an amino acid change have been identified in $6 \%$ of a Dutch population and associated with an increased sensitivity to glucocorticoids resulting in a trend towards decreased BMD (Huizenga et al. 1998). This polymorphic locus carries a great potential to explain major interindividual variations in the rate of bone loss in glucocorticoid-treated patients.

The PTH gene has been shown to display polymorphisms (Mullersman et al. 1992, Hosoi et al. 1999, Kanzawa et al. 1999). In the study by Hosoi et al. (1999), heterozygosity in an intronic polymorphism in the PTH gene was found to be associated with higher lumbar spine BMD in 383 healthy postmenopausal Japanese women. However, serum PTH levels were absolutely identical among homozygotes and heterozygotes. Moreover, a small study in 91 healthy Caucasian women who were premenopausal at entry and were prospectively investigated for a median period of 20 years with repeated bone radiographs has recently suggested that PTH gene polymorphisms could explain $7-9 \%$ of the variance in bone dimensions and their changes with age, such as the cross-sectional cortical area of long bones (Gong et al. 1999). Regarding PTH/PTHrP receptor, although microsatellite markers in the vicinity of the PTH receptor 1 gene have clearly identified this locus as an important potential determinant of bone mass (Duncan et al. 1999), to date no polymorphisms have directly been identified in this gene sequence in relation to BMD.

Eventually, variable number tandem repeats $(\mathrm{AGC}) \mathrm{n}$ in the androgen receptor gene have recently been shown to be associated with BMD at the femoral neck and lumbar spine as well as with femoral neck BMD changes over 3 years in 261 preand perimenopausal women (Sowers et al. 1999). Due to the increasing evidence of a contribution of androgens in bone mass determination in women as much as in men, these data are of great interest and clearly deserve confirmation in other cohorts.

\section{Beyond hormones}

A number of polymorphic genes coding for proteins acting beyond the hormone-receptor level seem to offer great promise in explaining some of the variance in the susceptibility to osteoporosis. Among them, functional allelic variants in the genes coding for the TGF- $\beta 1$ and IL-6, two cytokines acting downstream of the ER to directly regulate bone resorption and/or formation (Manolagas 


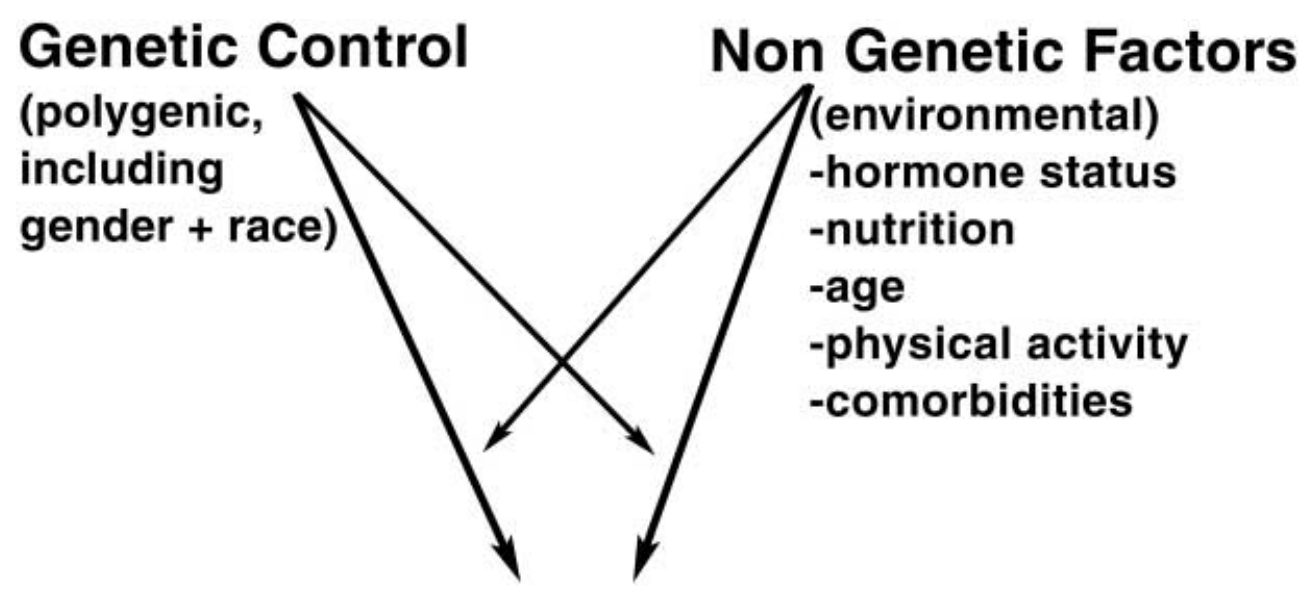

\section{Bone Mass}

\section{With skeletal site specificity}

FIGURE 4. Interaction of genetic and non-genetic factors on bone mass.

1998), have recently been associated with osteoporosis and/or the rate of bone turnover in postmenopausal women. Thus, a common $\mathrm{T}>\mathrm{C}$ transition polymorphism in the TGF- $\beta 1$ gene exon 1 is significantly associated with serum TGF- $\beta 1$ concentrations as well as the prevalence of osteoporosis in 239 unrelated postmenopausal Japanese women and susceptibility to fracture (Yamada et al. 1998, 2000). Moreover, in the same cohort, this polymorphism has been associated with the rate of bone loss as well as the response to vitamin D supplements (Yamada et al. 2000). A higher BMD was also observed in adolescents with the CC genotype, suggesting that this polymorphism could influence peak bone mass as well (Yamada et al. 1999). However, these findings require confirmation in populations of other ethnic origin. Another important, although rare, polymorphism in the TGF- $\beta 1$ gene occurring as a one-base $(\mathrm{C})$ deletion in intron 4 has also been associated with severe osteoporosis and increased bone turnover in Caucasians (Langdahl et al. 1997, Bertoldo et al. 2000).

A common $\mathrm{G}>\mathrm{C}$ polymorphism at position -174 in the IL-6 gene promoter has recently been shown to affect the gene transcriptional activity (Fishman et al. 1998). These allelic variants influence the level of bone resorption, as evaluated by a marker of collagen I degradation - the serum C-telopeptide of type I collagen - in postmenopausal women (Ferrari et al. 2000).

\section{CONCLUSIONS}

Bone mass gain during growth as well as postmenopausal and age-related bone loss display skeletal-site specificity in terms of magnitude and kinetics. Bone strength, and thereby fracture risk, depends on bone size, volumetric bone density, microarchitecture, and intrinsic bony tissue properties. The risk of osteoporosis depends on the achievement of peak bone mass, which is mostly determined by changes in bone size with minimal modifications in volumetric density, and in the amount of bone loss, which is mainly the consequence of alteration in volumetric bone density and in microarchitecture. All these processes are controlled by complex and selective genetic, hormonal, nutritional and other environmental factors, which tightly interact (Fig. 4). Because of the multiple influences on bone homeostasis and the heterogeneity of the mechanisms governing skeletal growth and bone loss, the genetic control of bone mass implicates numerous genes of variable importance during an individual's lifespan. The recent emergence of candidate genes, particularly controlling hormone levels and their receptors, associated with BMD and/or bone remodeling, has opened new concepts in the comprehension of the pathophysiology of osteoporosis. Among these genes, allelic polymorphisms for the receptors recognizing the vitamin $\mathrm{D}$ active metabolite (calcitriol), estradiol, and PTH could be associated with bone mass. Most importantly, these 
polymorphic genes, as well as those coding for TGF- $\beta$ and IL-6, have a potential interest to understand, and eventually predict, the individual response to anti-osteoporotic therapies. Thus, the possible implication of the PTH receptor 1 gene in the response to $\mathrm{PTH}$ raises great interest with respect to the recently reported effects of PTH in the prevention of fracture risk (Neer et al. 2000). However, any of these polymorphic loci is very unlikely to represent per se a definite marker of osteoporosis, particularly since their influence cannot be dissociated from environmental factors (Ferrari et al. 1998e). Therefore, to reliably appraise the role of genetics in osteoporosis as a highly complex model, one has to gather information from different sources. These include association studies in well-defined demographically and homogeneous populations, and randomized controlled trials looking at the bone response to hormonal and/or environmental changes, combined with experimental investigations assessing the molecular mechanisms implicated in the interaction between genotype and phenotype.

\section{ACKNOWLEGEMENTS}

We thank Mrs M Perez for her invaluable help in the preparation of the manuscript. The work from our group quoted in this review was supported by the Swiss National Science Foundation (grants no. 32-32415.91 and no. 31-40758.94).

\section{REFERENCES}

Ames SK, Ellis KJ, Gunn SK, Copeland KC \& Abrams SA 1999 Vitamin D receptor gene FokI polymorphism predicts calcium absorption and bone mineral density in children. Fournal of Bone and Mineral Research 14 740-746.

Ammann P, Rizzoli R, Meyer JM \& Bonjour JP 1996 Bone density and shape as determinants of bone strength in IGF-I and/or pamidronate-treated ovariectomized rats. Osteoporosis International 6 219-227.

Aniansson A, Zetterberg C, Hedberg M \& Henriksson K 1984 Impaired muscle function with aging. Clinical Orthopaedics and Related Research 191 193-201.

Arai H, Miyamoto KI, Taketani Y, Yamamoto H, Iemori Y, Morita K, Tonai T, Nishisho T, Mori S \& Takeda E 1997 A vitamin $\mathrm{D}$ receptor gene polymorphism in the translation initiation codon: effect on protein activity and relation to bone mineral density in Japanese women. Fournal of Bone and Mineral Research 12 915-921.

Bagi CM, DeLeon E, Ammann P, Rizzoli R \& Miller SC 1996 Histo-anatomy of the proximal femur in rats: impact of ovariectomy on bone mass, structure, and stiffness. Anatomical Record 245 633-644.

Bagi CM, Ammann P, Rizzoli R \& Miller SC 1997 Effect of estrogen deficiency on cancellous and cortical bone structure and strength of the femoral neck in rats. Calcified Tissue International 61 336-344.
Barger-Lux MJ, Heaney RP, Hayes J, DeLuca HF, Johnson ML \& Gong G 1995 Vitamin D receptor gene polymorphisms, bone mass, body size, and vitamin $\mathrm{D}$ receptor density. Calcified Tissue International 57 161-162.

Barthe N, Basse-Cathalinat B, Meunier PJ, Ribot C, Marchandise X, Sabatier JP, Braillon P, Thevenot J \& Sutter B 1998 Measurement of bone mineral density in mother-daughter pairs for evaluating the family influence on bone mass acquisition: a GRIO survey. Osteoporosis International 8 379-384.

Berg JP, Lehmann EH, Stakkestad JA, Haug E \& Halse J 2000 IGF-I gene microsatellite polymorphisms and serum levels of insulin-like growth factor I (IGF-I), IGF-binding protein 3 and bone mineral density in young individuals. Proceedings of the Annual Meeting of the Endocrine Society. Abstract no. 1743.

Bertoldo F, D'Agruma L, Furlan F, Colapietro F, Lorenzi MT, Maiorano N, Iolascon A, Zelante L, Locascio V \& Gasparini P 2000 Transforming growth factor-beta1 gene polymorphism, bone turnover, and bone mass in Italian postmenopausal women. Fournal of Bone and Mineral Research 15 634-639.

Bilezikian JP, Kurland ES \& Rosen CJ 1999 Male skeletal health and osteoporosis. Trends in Endocrinology and Metabolism 10 244-250.

Bonjour JP \& Rizzoli R 1996 Bone acquisition in adolescence. In Osteoporosis, pp 465-476. Eds R Marcus, D Feldman \& J Kelsey. San Diego: Academic Press.

Bonjour JP, Theintz G, Buchs B, Slosman D \& Rizzoli R 1991 Critical years and stages of puberty for spinal and femoral bone mass accumulation during adolescence. Fournal of Clinical Endocrinology and Metabolism 73 555-563.

Bonjour JP, Carrié AL, Ferrari S, Clavien H, Slosman D, Theintz G \& Rizzoli R 1997 Calcium enriched foods and bone mass growth in prepubertal girls: a randomized, double-blind, placebo-controlled trial. Fournal of Clinical Investigation 99 1287-1294.

Canalis E, McCarthy TL \& Centrella M 1991 Growth factors and cytokines in bone cell metabolism. Annual Review of Medicine 42 17-24.

Carani C, Qin K, Simoni M, Faustini-Fustini M, Serpente S, Boyd J, Korach KS \& Simpson ER 1997 Effect of testosterone and estradiol in a man with aromatase deficiency. New England Fournal of Medicine 337 91-95.

Castaneda C, Charnley JM, Evans WJ \& Crim MC 1995 Elderly women accomodate to a low-protein diet with losses of body cell mass, muscle function, and immune response. American Fournal of Clinical Nutrition 62 30-39.

Caverzasio J \& Bonjour JP 1989 Insulin-like growth factor I stimulates $\mathrm{Na}$-dependent $\mathrm{Pi}$ transport in cultured kidney cells. American Fournal of Physiology 257 F712-F717.

Caverzasio J, Montessuit C \& Bonjour JP 1990 Stimulatory effect of insulin-like growth factor-I on renal Pi transport and plasma 1,25-dihydroxyvitamin D3. Endocrinology 127 453-459.

Chapuy MC, Arlot ME, Duboeuf F, Brun J, Crouzet B, Arnaud S, Delmas PD \& Meunier PJ 1992 Vitamin D3 and calcium to prevent hip fractures in elderly women. New England Fournal of Medicine 327 1637-1642.

Chevalley T, Rizzoli R, Nydegger V, Slosman D, Rapin CH, Michel JP, Vasey H \& Bonjour JP 1994 Effects of calcium supplements on femoral bone mineral density and vertebral fracture rate in vitamin-D-replete elderly patients. Osteoporosis International 4 245-252.

Chevalley T, Rizzoli R, Manen D, Caverzasio J \& Bonjour JP 1998 Arginine increases insulin-like growth factor-I production and collagen synthesis in osteoblast-like cells. Bone 23 103-109. 
Christakos S, Raval-Pandya M, Wernyj RP \& Yang W 1996 Genomic mechanisms involved in the pleiotropic actions of 1,25-dihydroxyvitamin $\mathrm{D}_{3}$. Biochemical Fournal 316 361-371.

Cohen-Solal ME, Baudoin C, Omouri M, Kuntz D \& De Vernejoul MC 1998 Bone mass in middle-aged osteoporotic men and their relatives: familial effect. Fournal of Bone and Mineral Research 13 1909-1914.

Cooper GS \& Umbach DM 1996 Are vitamin D receptor polymorphisms associated with bone mineral density? A meta-analysis. Fournal of Bone and Mineral Research 11 1841-1849.

Danielson ME, Cauley JA, Baker CE, Newman AB, Dorman JS, Towers JD \& Kuller LH 1999 Familial resemblance of bone mineral density (BMD) and calcaneal ultrasound attenuation: the BMD in mothers and daughters study. Fournal of Bone and Mineral Research 14 102-110.

Dawson-Hughes B, Harris SS \& Finneran S 1995 Calcium absorption on high and low calcium intakes in relation to vitamin D receptor genotype. Fournal of Clinical Endocrinology and Metabolism 80 3657-3661.

Dawson-Hughes B, Harris SS, Krall EA \& Dallal GE 1997 Effect of calcium and vitamin $\mathrm{D}$ supplementation on bone density in men and women 65 years of age or older. New England Fournal of Medicine 337 670-676.

Deng HW, Li J, Li JL, Johnson M, Gong G, Davis KM \& Recker RR 1998 Change of bone mass in postmenopausal Caucasian women with and without hormone replacement therapy is associated with vitamin D receptor and estrogen receptor genotypes. Human Genetics 103 576-585.

Drinkwater BL, Nilson K, Chesnut CH III, Bremner WJ, Shainholtz S \& Southworth MB 1984 Bone mineral content of amenorrheic and eumenorrheic athletes. New England Fournal of Medicine 311 277-281.

Duncan EL, Brown MA, Sinsheimer J, Bell J, Carr AJ, Wordsworth BP \& Wass JA 1999 Suggestive linkage of the parathyroid receptor type 1 to osteoporosis. Fournal of Bone and Mineral Research 14 1993-1999.

Eccleshall TR, Garnero P, Gross C, Delmas PD \& Feldman D 1998 Lack of correlation between start codon polymorphism of the vitamin D receptor gene and bone mineral density in premenopausal French women: the OFELY study. Fournal of Bone and Mineral Research 13 31-35.

Ensrud KE, Palermo L, Black DM, Cauley J, Jergas M, Orwoll ES, Nevitt MC, Fox KM \& Cummings SR 1995 Hip and calcaneal bone loss increase with advancing age: longitudinal results from the study of osteoporotic fractures. Fournal of Bone and Mineral Research 10 1778-1787.

Ensrud KE, Stone K, Cauley JA, White C, Zmuda JM, Nguyen TV, Eisman JA \& Cummings SR 1999 Vitamin D receptor gene polymorphisms and the risk of fractures in older women. For the Study of Osteoporotic Fractures Research Group. Fournal of Bone and Mineral Research 14 $1637-1645$.

Ensrud KE, Duong T, Cauley JA, Heaney RP, Worl RL, Harris E \& Cummings SR 2000 Low fractional calcium absorption increases the risk for hip fracture in women with low calcium intake. Study of Osteoporotic Fractures Research Group. Annals of Internal Medicine 132 345-353.

Ferrari S, Rizzoli R, Chevalley T, Slosman D, Eisman JA \& Bonjour JP 1995 Vitamin-D-receptor-gene polymorphisms and change in lumbar-spine bone mineral density. Lancet 345 423-424.

Ferrari S, Bonjour JP \& Rizzoli R $1998 a$ The vitamin D receptor gene and calcium metabolism. Trends in Endocrinology and Metabolism 9 259-265.

Ferrari S, Rizzoli R, Slosman D \& Bonjour JP $1998 b$ Familial resemblance for bone mineral mass is expressed before puberty. Fournal of Clinical Endocrinology and Metabolism $\mathbf{8 3}$ 358-361.

Ferrari S, Rizzoli R, Slosman D \& Bonjour JP 1998c Do dietary calcium and age explain the controversy surrounding the relationship between bone mineral density and vitamin D receptor gene polymorphisms. Fournal of Bone and Mineral Research 13 925-930.

Ferrari S, Rizzoli R, Manen D, Slosman D \& Bonjour JP 1998d Vitamin D receptor gene start codon polymorphisms (FokI) and bone mineral density: interaction with age, dietary calcium and $3^{\prime}$-end region polymorphisms. Fournal of Bone and Mineral Research 13 363-370.

Ferrari S, Rizzoli R \& Bonjour JP 1998e Heritable and nutritional influences on bone mineral mass. Aging $\mathbf{1 0}$ 205-213.

Ferrari S, Manen D, Bonjour JP, Slosman D \& Rizzoli R 1999 Bone mineral mass and calcium and phosphate metabolism in young men: relationships with vitamin $\mathrm{D}$ receptor allelic polymorphisms. Fournal of Clinical Endocrinology and Metabolism 84 2043-2048.

Ferrari S, Garnero P, Emond S, Montgomery H, Humphries SE \& Greenspan S 2001 A functional polymorphic variant in the interleukin- 6 gene promoter associated with low bone resorption in postmenopausal women. Arthritis and Rheumatism (In Press).

Feskanich D, Hunter DJ, Willett WC, Hankinson SE, Hollis BW, Hough HL, Kelsey KT \& Colditz GA 1998 Vitamin D receptor genotype and the risk of bone fractures in women. Epidemiology 9 535-539.

Fishman D, Faulds G, Jeffery R, Mohamed-Ali V, Yudkin JS, Humphries S \& Woo P 1998 The effect of novel polymorphisms in the interleukin-6 (IL-6) gene on IL-6 transcription and plasma IL-6 levels, and an association with systemic-onset juvenile chronic arthritis. Fournal of Clinical Investigation 102 1369-1376.

Fournier PE, Rizzoli R, Slosman DO, Theintz G \& Bonjour JP 1997 Asynchrony between the rates of standing height gain and bone mass accumulation during puberty. Osteoporosis International 7 525-532.

Froesch ER, Schmid C, Schwander J \& Zapf J 1985 Actions of insulin-like growth factors. Annual Review of Physiology 47 443-467.

Garn SM, Wagner B, Rohmann CG \& Ascoli W 1967 Further evidence for continuing bone expansion. American Fournal of Physical Anthropology 26 313-318.

Garn SM, Rohnmann CG, Wagner B \& Ascoli W 1968 Continuing bone growth throughout life: a general phenomenon. American Fournal of Physical Anthropology 28 219-222.

Garnero P, Borel O, Sornay-Rendu E \& Delmas PD 1995 Vitamin D receptor gene polymorphisms do not predict bone turnover and bone mass in healthy premenopausal women. Fournal of Bone and Mineral Research $\mathbf{1 0}$ $1283-1288$.

Garnero P, Arden NK, Griffiths G, Delmas PD \& Spector TD $1996 a$ Genetic influence on bone turnover in postmenopausal twins. Fournal of Clinical Endocrinology and Metabolism $\mathbf{8 1}$ 140-146.

Garnero P, Borel O, Sornay-Rendu E, Arlot ME \& Delmas PD $1996 b$ Vitamin D receptor gene polymorphisms are not related to bone turnover, rate of bone loss, and bone mass in postmenopausal women: the OFELY study. Fournal of Bone and Mineral Research 11 827-834.

Gennari L, Becherini L, Masi L, Mansani R, Gonnelli S, Cepollaro C, Martni S, Montagnani A, Lentini G, Becorpi AM \& Brandi ML 1998 Vitamin D and estrogen receptor allelic variants in Italian postmenopausal women: evidence of multiple gene contribution to bone mineral density. 
Fournal of Clinical Endocrinology and Metabolism 83 939-944.

Geusens P, Cantatore F, Nijs J, Proesmans W, Emma F \& Dequeker J 1991 Heterogeneity of growth of bone in children at the spine, radius and total skeleton. Growth, Development and Aging 55 249-256.

Giguère Y, Dodin S, Blanchet C, Morgan K \& Rousseau F 2000 The association between heel ultrasound and hormone replacement therapy is modulated by a two-locus vitamin D and estrogen receptor genotype. Fournal of Bone and Mineral Research 15 1076-1084.

Gilsanz V 1998 Phenotype and genotype of osteoporosis. Trends in Endocrinology and Metabolism 9 184-190.

Gilsanz V, Gibbens DT, Roe TF, Carlson M, Senac MO, Boechat MI, Huang HK, Schulz EE, Libanati CR \& Cann CC 1988 Vertebral bone density in children: effect of puberty. Radiology 166 847-850.

Gilsanz V, Roe TF, Mora S, Costin G \& Goodman WG 1991 Changes in vertebral bone density in black girls and white girls during childhood and puberty. New England Fournal of Medicine 325 1597-1600.

Gilsanz V, Kovanlikaya A, Costin G, Roe TF, Sayre J \& Kaufman F 1997 Differential effect of gender on the sizes of the bones in the axial and appendicular skeletons. Fournal of Clinical Endocrinology and Metabolism $\mathbf{8 2}$ 1603-1607.

Gilsanz V, Skaggs DL, Kovanlikaya A, Sayre J, Luiza Loro M, Kaufman F \& Korenman SG 1998 Differential effect of race on the axial and appendicular skeletons of children. Fournal of Clinical Endocrinology and Metabolism $\mathbf{8 3}$ 1420-1427.

Gilsanz V, Rogers J, Bilezikian JP, Friez JK \& Rosen C 1999 A simple sequence repeat in the IGF-I gene and its relationship to serum IGF-I and peak bone mass in pupertal boys and girls. Proceedings of the Annual Meeting of the American Endocrine Society. Abstract no. OR23-2.

Glastre C, Braillon P, David L, Cochat P, Meunier PJ \& Delmas PD 1990 Measurement of bone mineral content of the lumbar spine by dual energy X-ray absorptiometry in normal children: correlations with growth parameters. Fournal of Clinical Endocrinology and Metabolism 70 1330-1333.

Gong G, Johnson ML, Barger-Lux MJ \& Heaney RP 1999 Association of bone dimensions with a parathyroid hormone gene polymorphism in women. Osteoporosis International 9 307-311.

Gong Y, Vikkula M, Boon L, Liu J, Beighton P, Ramesar R, Peltonen L, Somer H, Hirose T, Dallapiccola B, De Paepe A, Swoboda W, Zabel B, Superti-Furga A, Steinmann B, Brunner HG, Jans A, Boles RG, Adkins W, van den Boogaard MJ, Olsen BR \& Warman ML 1996 Osteoporosis-pseudoglioma syndrome, a disorder affecting skeletal strength and vision, is assigned to chromosome region 11q12-13. American Fournal of Human Genetics 59 $146-151$

Goodman-Gruen D \& Barrett-Connor E 1997 Epidemiology of insulin-like factor-I in elderly men and women. The Rancho Bernardo Study. American Fournal of Epidemiology 145 970-976.

Graafmans WC, Lips P, Ooms ME, van Leeuwen JP, Pols HAP \& Uitterlinden AG 1997 The effect of vitamin D supplementation on the bone mineral density of the femoral neck is associated with vitamin D receptor genotype. Fournal of Bone and Mineral Research 12 1241-1245.

Greendale GA, Edelstein S \& Barrett-Connor E 1997 Endogenous sex steroids and bone mineral density in older women and men: the Rancho Bernardo study. Fournal of Bone and Mineral Research 12 1833-1843.
Gregg EW, Wolf RL, Kriska AM, Ferrell RE, Salamone LM, Black D, Kuller LH \& Cauley JA 1996 Does the relationship between vitamin $\mathrm{D}$ receptor genotypes and bone parameters vary with physical activity level? Fournal of Bone and Mineral Research 11 (Suppl 1) S210.

Gregg EW, Kriska AM, Salamone LM, Wolf RL, Roberts MM, Ferrell RE, Anderson SJ, Kuller LH \& Cauley JA 1999 Correlates of quantitative ultrasound in the Women's Healthy Lifestyle Project. Osteoporosis International 10 416-424.

Gross C, Eccleshall TR, Malloy PJ, Villa ML, Marcus R \& Feldman D 1996 The presence of a polymorphism at the translation initiation site of the vitamin $\mathrm{D}$ receptor gene is associated with low bone mineral density in postmenopausal Mexican-American women. Bone and Mineral Research 11 1850-1855.

Hammerman MR 1987 Insulin-like growth factors and aging. Endocrinology and Metabolism Clinics of North America $\mathbf{1 6}$ 995-1011.

Han KO, Moon G, Kang YS, Chung HY, Min HK \& Han IK 1997 Nonassociation of estrogen receptor genotypes with bone mineral density and estrogen responsiveness to hormone replacement therapy in Korean postmenopausal women. Fournal of Clinical Endocrinology and Metabolism 82 991-995.

Han ZH, Palnitkar S, Rao DS, Nelson D \& Parfitt AM 1996 Effects of ethnicity and age or menopause on the structure and geometry of iliac bone. Fournal of Bone and Mineral Research 11 1967-1975.

Harris SS, Eccleshall TR, Gross C, Dawson-Hughes B \& Feldman D 1997 The vitamin D receptor start codon polymorphism (FokI) and bone mineral density in premenopausal American black and white women. Fournal of Bone and Mineral Research 12 1043-1048.

Haussler MR, Haussler CA, Jurutka PW, Thompson PD, Hsieh JC, Remus LS, Selznick SH \& Whitfield GK 1997 The vitamin D hormone and its nuclear receptor: molecular actions and disease states. Fournal of Endocrinology 154 S57-S73.

Heishi M, Tazawa H, Matsuo T, Saruta T, Hanaoka M \& Tsukamoto Y 2000 A novel Van91 I polymorphism in the 1 st intron of the parathyroid hormone $(\mathrm{PTH}) / \mathrm{PTH}$-related peptide $(\mathrm{PTHrP})$ receptor gene and its effect on the urinary cAMP response to PTH. Biological and Pharmaceutical Bulletin 23 386-389.

Hosoi T, Miyao M, Inoue S, Hoshino S, Shiraki M, Orimo H \& Ouchi Y 1999 Association study of parathyroid hormone gene polymorphism and bone mineral density in Japanese postmenopausal women. Calcified Tissue International 64 205-208.

Huizenga NA, Koer JW, De Lange P, Pols HA, Stolk RP, Burger H, Grobbee DE, Brinkmann AO, De Jong FH \& Lamberts SW 1998 A polymorphism in the glucocorticoid receptor gene may be associated with an increased sensitivity to glucocorticoids in vivo. Fournal of Clinical Endocrinology and Metabolism 83 144-151.

Hustmyer F, Peacock M, Hui S, Johnston CC \& Christian J 1994 Bone mineral density in relation to polymorphism at the vitamin D receptor gene locus. Fournal of Clinical Investigation 94 2130-2134.

Johnson ML, Gong G, Kimberling W, Recker SM, Kimmel DB \& Recker RB 1997 Linkage of a gene causing high bone mass to human chromosome 11 (11q12-13). American Fournal of Human Genetics 60 1326-1332.

Jørgensen HL, Schøller J, Sand JC, Bjuring M, Hassager C \& Christiansen C 1996 Relation of common allelic variation at vitamin $\mathrm{D}$ receptor locus to bone mineral density and postmenopausal bone loss: cross sectional and 
longitudinal population study. British Medical Fournal 313 586-590.

Kanis JA, Devogelaer JP \& Gennari C 1996 Practical guide for the use of bone mineral measurements in the assessment of treatment of osteoporosis: a position paper of the European Foundation for Osteoporosis and Bone Disease. The Scientific Advisory Board and the Board of National Societies. Osteoporosis International 6 256-261.

Kannus P, Palvanen M, Kaprio J, Parkkari J \& Koskenvuo M 1999 Genetic factors and osteoporotic fractures in elderly people: prospective 25 year follow-up of a nationwide cohort of elderly Finnish twins. British Medical Fournal 319 1334-1337.

Kanzawa M, Sugimoto T, Kobayashi T, Kobayashi A \& Chihara K 1999 Parathyroid hormone gene polymorphisms in primary hyperparathyroidism. Clinical Endocrinology $\mathbf{5 0}$ 583-588.

Katzman DK, Bachrach LK, Carter DR \& Marcus R 1991 Clinical and anthropometric correlates of bone mineral acquisition in healthy adolescent girls. Fournal of Clinical Endocrinology and Metabolism 73 1332-1339.

Kelly PJ, Eisman JA \& Sambrook PN 1990 Interaction of genetic and environmental influences on peak bone density. Osteoporosis International 1 56-60.

Kelly PJ, Morrison NA, Sambrook PN, Nguyen TV \& Eisman JA 1995 Genetic influences on bone turnover, bone density and fracture. European Fournal of Endocrinology 133 265-271.

Khosla S, Atkinson EJ, Melton LJ 3rd \& Riggs BL 1997 Effects of age and estrogen status on serum parathyroid hormone levels and biochemical markers of bone turnover in women: a population-based study. Fournal of Clinical Endocrinology and Metabolism 82 1522-1527.

Kiel DP, Myers RH, Cupples A, Kong XF, Zhu XH, Ordovas J, Schaefer EJ, Felson DT, Rush D, Wilson PWF, Eisman JA \& Holick MF 1997 The Bsm I vitamin D receptor restriction fragment length polymorphism (bb) influences the effect of calcium intake on bone mineral density. Fournal of Bone and Mineral Research 12 1049-1057.

Kikuchi R, Uemura T, Gorai I, Ohno S \& Minaguchi H 1999 Early and late postmenopausal bone loss is associated with Bsm I vitamin D receptor gene polymorphism in Japanese women. Calcified Tissue International 64 102-106.

Klotzbuecher CM, Ross PD, Landsman PB, Abbott TA 3rd \& Berger M 2000 Patients with prior fractures have an increased risk of future fractures: a summary of the literature and statistical synthesis. Fournal of Bone and Mineral Research 15 721-739.

Kobayashi S, Inoue S, Hosoi T, Ouchi Y, Shiraki M \& Orimo H 1996 Association of bone mineral density with polymorphism of the estrogen receptor gene. Fournal of Bone and Mineral Research 11 306-311.

Koller DL, Rodriguez LA, Christian JC, Slemenda CW, Econs MJ, Hui SL, Morin P, Conneally PM, Joslyn G, Curran ME, Peacock M, Johnston CC \& Foroud T 1998 Linkage of a QTL contributing to normal variation in bone mineral density to chromosome 11q12-13. Fournal of Bone and Mineral Research 13 1903-1908.

Krall EA \& Dawson-Hughes B 1993 Heritable and life-style determinants of bone mineral density. Fournal of Bone and Mineral Research 8 1-9.

Krall EA, Parry P, Lichter JB \& Dawson-Hughes B 1995 Vitamin D receptor alleles and rates of bone loss: influences of years since menopause and calcium intake. Fournal of Bone and Mineral Research 10 978-984.

Langdahl BL, Knudsen JY, Jensen HK, Gregersen N \& Eriksen EF 1997 A sequence variation: 713-8 delC in the transforming growth factor-beta 1 gene has higher prevalence in osteoporotic women than in normal women and is associated with very low bone mass in osteoporotic women and increased bone turnover in both osteoporotic and normal women. Bone 20 289-294.

Langlois JA, Rosen CJ, Visser M, Hannan MT, Harris T, Wilson PW \& Kiel DP 1998 Association between insulin-like growth factor I and bone mineral density in older women and men: the Framingham Heart Study. Fournal of Clinical Endocrinology and Metabolism 83 4257-4262.

Laval-Jeantet AM, Bergot C, Carroll R \& Garcia-Schaefer F 1983 Cortical bone senescence and mineral bone density of the humerus. Calcified Tissue International 35 268-272.

Lorentzon M, Lorentzon R \& Nordstrom P 2000 Vitamin D receptor gene polymorphism is associated with birth height, growth to adolescence, and adult stature in healthy Caucasian men: a cross-sectional and longitudinal study. Fournal of Clinical Endocrinology and Metabolism $\mathbf{8 5}$ 1666-1670.

Luckey MM, Wallenstein S, Lapinski R \& Meier DE 1996 A prospective study of bone loss in African-American and white women - a clinical research center study. Fournal of Clinical Endocrinology and Metabolism 81 2948-2956.

Manolagas SC 1998 The role of IL-6 type cytokines and their receptors in bone. Annals of the New York Academy of Sciences 840 194-204.

Masi L, Becherini L, Colli E, Gennari L, Mansani R, Falchetti A, Becorpi AM, Cepollaro C, Gonnelli S, Tanini A \& Brandi ML 1998 Polymorphisms of the calcitonin receptor gene are associated with bone mineral density in postmenopausal Italian women. Biochemical and Biophysical Research Communications 248 190-195.

Matkovic V, Jelic T, Wardlaw GM, Ilich JZ, Goel PK, Wright JK, Andon MB, Smith KT \& Heaney RP 1994 Timing of peak bone mass in Caucasian females and its implication for the prevention of osteoporosis - inference from a cross-sectional model. Fournal of Clinical Investigation 93 799-808

Matsuyama T, Ishii S, Tokita A, Yabuta K, Yamamori S, Morrison NA \& Eisman JA 1995 Vitamin D receptor genotypes and bone mineral density. Lancet 345 1238-1239.

Mazess RB, Barden HS, Ettinger M, Johnston C, Dawson-Hughes B, Baran D, Powell M \& Notelovitz M 1987 Spine and femur density using dual-photon absorptiometry in US white women. Bone and Mineral 2 211-219.

Miyao M, Hosoi T, Inoue S, Hoshino S, Shiraki M, Orimo H \& Ouchi Y 1998 Polymorphism of insulin-like growth factor I gene and bone mineral density. Calcified Tissue International 63 306-311.

Mizunuma H, Hosoi T, Okano H, Soda M, Tokizawa T, Kagami I, Miyamoto S, Ibuki Y, Inoue S, Shiraki M \& Ouchi Y 1997 Estrogen receptor gene polymorphism and bone mineral density at the lumbar spine of pre- and postmenopausal women. Bone 21 379-383.

Morrison NA, Qi JC, Tokita A, Kelly PJ, Crofts L, Nguyen TV, Sambrook PN \& Eisman JA 1994 Prediction of bone density from vitamin D receptor alleles. Nature 367 284-287.

Mosekilde L \& Mosekilde L 1990 Sex differences in age-related changes in vertebral body size, density and biomechanical competence in normal individuals. Bone 11 67-73.

Mullersman JE, Shields JJ \& Saha K 1992 Characteristics of two novel polymorphisms at the human parathyroid hormone gene locus. Human Genetics 88 589-592.

Neer RM, Arnaud C, Zanchetta JR, Prince R, Gaich GA, Reginster JY, Hodsman AB, Erickson EF, Mellstrom D, Ish-Shalom et al. 2000 Recombinant human PTH $[\mathrm{rhPTH}(1-34)]$ reduces the risk of spine and non-spine fractures in postmenopausal osteoporosis. Proceedings of the 
Annual Meeting of the American Endocrine Society. Abstract no. 173.

Nguyen TV, Howard GM, Kelly PJ \& Eisman JA 1998 Bone mass, lean mass, and fat mass: same genes or same environments? American Fournal of Epidemiology 147 3-16.

Palmer G, Bonjour JP \& Caverzasio J 1996 Stimulation of inorganic phosphate transport by insulin-like growth factor I and vanadate in opossum kidney cells is mediated by distinct protein tyrosine phosphorylation processes. Endocrinology 137 4699-4705.

Palmer G, Bonjour JP \& Caverzasio J 1997 Expression of a newly identified phosphate transporter/retrovirus receptor in human SaOS-2 osteoblast-like cells and its regulation by insulin-like growth factor I. Endocrinology 138 5202-5209.

Parsons JT, Prentice A, Smith EA, Cole TJ \& Compston JE 1996 Bone mineral mass consolidation in young British adults. Fournal of Bone and Mineral Research 11 264-274.

Pinilla TP, Boardman KC, Bouxsein ML, Myers ER \& Hayes WC 1996 Impact direction from a fall influences the failure load of the proximal femur as much as age-related bone loss. Calcified Tissue International 58 231-235.

Pocock NA, Eisman JA, Hopper JL, Yeates MG, Sambrook PN \& Ebert S 1987 Genetic determinants of bone mass in adults. A twin study. Fournal of Clinical Investigation $\mathbf{8 0}$ $706-710$

Quesada JM, Coopmans W, Ruiz B, Aljama P, Jans I \& Bouillon R 1992 Influence of vitamin D on parathyroid function in the elderly. Fournal of Clinical Endocrinology and Metabolism 75 494-501.

Ralston SH 1997 What determines peak bone mass and bone loss? Baillieres Clinical Rheumatology 11 479-494.

Reichel H, Koeffler HP \& Norman AW 1989 The role of the vitamin $\mathrm{D}$ endocrine system in health and disease. New England Fournal of Medicine 320 980-991.

Riggs BL, Wahner HW, Melton LJ III, Richelson LS, Judd HL \& Offord KP 1986 Rates of bone loss in the appendicular and axial skeletons of women: evidence for substantial vertebral bone loss before menopause. Fournal of Clinical Investigation 77 1487-1491.

Riggs BL, Khosla S \& Melton LJ III 1998 A unitary model for involutional osteoporosis: estrogen deficiency causes both type I and type II osteoporosis in postmenopausal women and contributes to bone loss in aging men. Fournal of Bone and Mineral Research 13 763-773.

Rizzoli R \& Bonjour JP 1997 Hormones and bones. Lancet 349 sI20-sI23.

Rizzoli R, Slosman D \& Bonjour JP 1995 Dual energy X-ray absorptiometry of lumbar spine and proximal femur in the diagnosis and follow-up of osteoporosis. American fournal of Medicine 98 33S-35S.

Rizzoli R, Ferrari S, Rosen C, Manen D \& Bonjour JP 2000 IGF-I gene $5^{\prime}$ polymorphism influences serum IGF-I levels in relation to dietary calcium intake in healthy young males. Fournal of Bone and Mineral Research 15 (Suppl 1) S364.

Rodin A, Murby B, Smith MA, Caleffi M, Fentiman I, Chapman MG \& Fogelman I 1990 Premenopausal bone loss in the lumbar spine and neck of femur: a study of 225 Caucasian women. Bone 11 1-5.

Rosen CJ \& Donahue LR 1995 Insulin-like growth factors: potential therapeutic options for osteoporosis. Trends in Endocrinology and Metabolism 6 235-241.

Rosen CJ, Kurland ES, Vereault D, Adler RA, Rackoff PJ, Craig WY, Witte S, Rogers J \& Bilezikian JP 1998 Association between serum insulin growth factor-I (IGF-I) and a simple sequence repeat in IGF-I gene: implications for genetic studies of bone mineral density. Fournal of Clinical Endocrinology and Metabolism 83 2286-2290.
Rubin LA, Hawker GA, Peltekova VD, Fielding LJ, Ridout R \& Cole DE 1999 Determinants of peak bone mass: clinical and genetic analyses in a young female Canadian cohort. Fournal of Bone and Mineral Research 14 633-643.

Sainz J, Van Tornout JM, Loro ML, Sayre J, Roe TF \& Gilsanz V 1997 Vitamin D-receptor gene polymorphisms and bone density in prepubertal American girls of Mexican descent. New England Fournal of Medicine 337 $77-82$.

Salamone LM, Glynn NW, Black DM, Ferrell RE, Palermo L, Epstein RS, Kuller LH \& Cauley JA 1996 Determinants of premenopausal bone mineral density: the interplay of genetic and lifestyle factors. Fournal of Bone and Mineral Research 11 $1557-1565$.

Salmen T, Heikkinen AM, Mahonen A, Kroger H, Komulainen M, Saarikoski S, Honkanen R \& Maenpaa PH 2000 Early postmenopausal bone loss is associated with $P v u I I$ estrogen receptor gene polymorphism in Finnish women: effect of hormone replacement therapy. Fournal of Bone and Mineral Research 15 315-321.

Schmid C \& Ernst M 1992 Insulin-like growth factors. In Cytokines and Bone Metabolism, pp 229-265. Ed M Gowen. Boca Raton, Ann Arbor, London: CRC Press.

Schürch MA, Rizzoli R, Slosman D, Vadas L, Vergnaud P \& Bonjour JP 1998 Protein supplements increase serum insulin-like growth factor-I levels and attenuate proximal femur bone loss in patients with recent hip fracture. A randomized, double-blind, placebo-controlled trial. Annals of Internal Medicine 128 801-809.

Seeman E 1997 From density to structure: growing up and growing old on the surfaces of bone. Fournal of Bone and Mineral Research 12 509-521.

Seeman E \& Hopper JL 1997 Genetic and environmental components of the population variance in bone density. Osteoporosis International 7 (Suppl 3) S10-S16.

Seeman E, Hopper JL, Bach LA, Cooper ME, Parkinson E, McKay J \& Jerums G 1989 Reduced bone mass in daughters of women with osteoporosis. New England Fournal of Medicine 320 554-558.

Seeman E, Szmukler GI, Formica C, Tsalamandris C \& Mestrovic R 1992 Osteoporosis in anorexia nervosa - the influence of peak bone density, bone loss, oral contraceptive use, and exercise. Fournal of Bone and Mineral Research 7 $1467-1474$.

Seeman E, Hopper JL, Young NR, Formica C, Goss P \& Tsalamandris C 1996 Do genetic factors explain associations between muscle strength, lean mass, and bone density? A twin study. American Fournal of Physiology 279 E320-E327.

Slemenda CW, Christian JC, Williams CJ, Norton JA \& Johnston CC 1991 Genetic determinants of bone mass in adult women: a reevaluation of the twin model and the potential importance of gene interaction on heritability estimates. Fournal of Bone and Mineral Research 6 561-567.

Slemenda CW, Turner CH, Peacock M, Christian JC, Sorbel J, Hui SL \& Johnston CC $1996 a$ The genetics of proximal femur geometry, distribution of bone mass and bone mineral densit. Osteoporosis International 6 178-182.

Slemenda C, Longcope C, Peacock M, Hui S \& Johnston CC $1996 b$ Sex steroids, bone mass and bone loss: a prospective study of pre-, peri-, and postmenopausal women. Fournal of Clinical Investigation 97 14-21.

Slemenda CW, Longcope C, Zhou L, Hui SL, Peacock M \& Johnston C 1997 Sex steroids and bone mass in older men: positive associations with serum estrogens and negative associations with androgens. Fournal of Clinical Investigation $1001755-1759$. 
Smith EP, Boyd J, Frank GR, Takahashi H, Cohen RM, Specker B, Williams TC, Lubahn DB \& Korach KS 1994 Estrogen resistance caused by a mutation in the estrogen-receptor gene in a man. New England Fournal of Medicine 331 1056-1061.

Snieder H, MacGregor AJ \& Spector TD 1998 Genes control the cessation of a woman's reproductive life: a twin study of hysterectomy and age at menopause. Fournal of Clinical Endocrinology and Metabolism 83 1875-1880.

Sowers M, Willing M, Burns T, Deschenes S, Hollis B, Crutchfield M \& Jannausch M 1999 Genetic markers, bone mineral density, and serum osteocalcin levels. Fournal of Bone and Mineral Research 14 1411-1419.

Taboulet J, Frenkian M, Frendo JL, Feingold N, Jullienne A \& De Vernejoul MC 1998 Calcitonin receptor polymorphism is associated with a decreased fracture risk in post-menopausal women. Human Molecular Genetics 7 2129-2133.

Takacs I, Koller DL, Peacock M, Christian JC, Hui SL, Conneally PM, Johnston CC Jr, Foroud T \& Econs MJ 1999 Sibling pair linkage and association studies between bone mineral density and the insulin-like growth factor I gene locus. Fournal of Clinical Endocrinology and Metabolism 84 4467-4471.

Tao C, Yu T, Garnett S, Briody J, Knight J, Woodhead H \& Cowell CT 1998 Vitamin D receptor alleles predict growth and bone density in girls. Archives of Diseases in Childhood $79488-493$.

Theintz G, Buchs B, Rizzoli R, Slosman D, Clavien H, Sizonenko PC \& Bonjour JP 1992 Longitudinal monitoring of bone mass accumulation in healthy adolescents: evidence for a marked reduction after 16 years of age at the levels of lumbar spine and femoral neck in female subjects. Fournal of Clinical Endocrinology and Metabolism 75 1060-1065.

Tokita A, Matsumoto H, Morrison NA, Tawa T, Miura Y, Fukamauchi K, Mitsuhashi N, Irimoto M, Yamamori S, Miura M, Watanabe T, Kuwabara Y, Yabuta K \& Eisman JA 1996 Vitamin D receptor alleles, bone mineral density and turnover in premenopausal Japanese women. Fournal of Bone and Mineral Research 11 1003-1009.

Trotter M \& Dixon BB 1974 Sequential changes in weight, density, and percentage ash weight of human skeletons from an early fetal period through old age. Anatomical Record $1791-18$.

Tsukamoto K \& Emi M 1998 A polymorphic CA repeat sequence at the human calcitonin locus. Fournal of Human Genetics 43 146-147.

Turner CH, Hsieh YF, Muller R, Bouxsein ML, Baylink DJ, Rosen CJ, Grynpas MD, Donahue LR \& Beamer WG 2000 Genetic regulation of cortical and trabecular bone strength and microstructure in inbred stains of mice. Fournal of Bone and Mineral Research 15 1126-1131.

Tylavsky FA, Bortz AD, Hancock RL \& Anderson JJB 1989

Familial resemblance of radial bone mass between premenopausal mothers and their college-age daughters. Calcified Tissue International 45 265-272.

Uitterlinden AG, Pols HAP, Burger H, Huang Q, Van Daele PLA, Van Duijn CM, Hofman A, Birkenhä ger JC \& Van Leeuwen JPTM 1996 A large-scale population-based study of the association of vitamin $\mathrm{D}$ receptor gene polymorphisms with bone mineral density. Fournal of Bone and Mineral Research 11 1241-1248.

Vanderschueren D, Van Herck E, Nijs J, Ederveen AG, De Coster R \& Bouillon R 1997 Aromatase inhibition impairs skeletal modeling and decreases bone mineral density in growing male rats. Endocrinology 138 2301-2307.

Vandevyver C, Vanhoof J, Declerck K, Stinissen P, Vandervorst C, Michiels L, Cassiman JJ, Boonen S, Raus J \& Geusens P 1999 Lack of association between estrogen receptor genotypes and bone mineral density, fracture history, or muscle strength in elderly women. Fournal of Bone and Mineral Research 14 1576-1582.

Weber JL \& May PE 1989 Abundant class of human DNA polymorphisms which can be typed using the polymerase chain reaction. American Fournal of Human Genetics 44 388-396.

Willing M, Sowers M, Aron D, Clark MK, Burns T, Bunten C, Crutchfield M, D’Agostino D \& Jannausch M 1998 Bone mineral density and its change in white women: estrogen and vitamin D receptor genotypes and their interaction. Fournal of Bone and Mineral Research 13 695-705.

Yamada Y, Miyauchi A, Goto J, Takagi Y, Okuizumi H, Kanematsu M, Hase M, Takai H, Harada A \& Ikeda K 1998 Association of a polymorphism of the transforming growth factor-beta1 gene with genetic susceptibility to osteoporosis in postmenopausal Japanese women. Fournal of Bone and Mineral Research 13 1569-1576.

Yamada Y, Hosoi T, Makimoto F, Tanaka H, Seino Y \& Ikeda K 1999 Transforming growth factor beta-1 gene polymorphism and bone mineral density in Japanese adolescents. American Fournal of Medicine 106 477-479.

Yamada Y, Harada A, Hosoi T, Miyauchi A, Ikeda K, Ohta H \& Shiraki M 2000 Association of transforming growth factor beta1 genotype with therapeutic response to active vitamin D for postmenopausal osteoporosis. Fournal of Bone and Mineral Research 15 415-420.

Zmuda JM, Cauley JA, Danielson ME, Wolf RL \& Ferrell RE 1997 Vitamin D receptor gene polymorphisms, bone turnover, and rates of bone loss in older African-American women. Fournal of Bone and Mineral Research 12 1446-1452.

Zmuda JM, Cauley JA \& Ferrell RE 1999 Recent progress in understanding the genetic susceptibility to osteoporosis. Genetic Epidemiology 16 356-367.

RECEIVED 8 September 2000 ACCEPTED 14 November 2000 